\title{
Assessment of service quality for complex technical devices based on the Jaynes' information principle
}

\author{
Arkadiy I. Maron \\ Associate Professor, Department of Business Analytics \\ National Research University Higher School of Economics \\ Address: 20, Myasnitskaya Street, Moscow, 101000, Russian Federation \\ E-mail:amaron@hse.ru
}

\begin{abstract}
The Jaynes' information principle (formalism) advanced for the solution of problems of statistical thermodynamics is applied to the solution of a task of assessing the fairness of a contractor who carries out restoration work on a technical system by the method of replacing elements.

The task is the following. The customer possesses a fleet of similar technical devices (for example, cars) certain elements of which are subject to planned replacement. According to the contract, such replacements are carried out by a contractor. Spare elements of three types can be used: new original, new non-original and restored elements. The contract specifies what percentage of spare elements of each type may be used. It is difficult for the customer to check what type of element has been applied. However, for an element of each type it is possible to calculate the average time before the next replacement will be required. The actual average time between requirements for replacement is fixed by the customer.

Based on these data and with the help of Jaynes' information principle, it is possible to find the most objective probabilities of using elements of the various types. Having compared these probabilities with restrictions specified in the contract, the customer draws a conclusion about the fairness of the contractor and, if necessary, takes appropriate action. According to Jaynes' principle, the most objective are probabilities for which entropy according to Shannon reaches a maximum under the set of restrictions. Respectively, the problem of finding their probabilities is simplified to a problem of finding the maximum nonlinear function under the set of restrictions. In this article, the task is formulated mathematically and solved for a case of three variables using the Lagrange method. Calculations for a real situation from the author's practice are given.
\end{abstract}

Key words: maintenance, probability, entropy, Jaynes' principle.

Citation: Maron A.I. (2016) Assessment of service quality for complex technical devices based on the Jaynes' information principle. Business Informatics, no. 4 (38), pp. 47-51. DOI: 10.17323/1998-0663.2016.4.47.51.

\section{Introduction}

$\mathrm{T}$ There are a great many tasks relating to determination of the probabilities of states in which some system is available at present, or was available in the past. However, it is practically impossible to calculate or to determine these probabilities statistically. For example, an organization carries out standard construction projects. Each project consists of certain stages (phases) [1]. At the end of each stage a certain result, for example, the base, walls, etc. is obtained. Delay of a stage's finish leads to delay of the end of the whole project. In the company it is always known how much is the delay of each project, and, as a rule, what are the reasons for such delays. However, these data are insufficient for determining relative probabilities of delays at various stages. This is explained by the fact that the frequency converges with probability rather slowly. Even in the case 
of standard projects, their number is usually not enough for a valid justification [2].

Another example concerns railway transport, where much attention is paid to increasing the reliability and safety of infrastructure facilities directly related with technological process of transportation of goods and passengers. Among infrastructure facilities, an important role belongs to railway automatic devices. Failures of such devices are fixed and investigated, especially if they lead to delays of trains. More attention is paid to dangerous failures, which result, or could lead to crashes [3]. In any case, a service department responsible to the failure is determined. At the same time, there are inevitable discrepancies which significantly influence the reliability of conclusions. That is why it is extremely difficult to find relative probabilities of failures relying on official statistics.

The examples show that the major factors which often make the statistical definition of states of technical and organizational systems impossible are insufficiency and unauthenticity of source data.

\section{Jaynes' principle and its capability}

Definition of the most probable power states is one of the most important problems of statistical thermodynamics. Gibbs received a distribution of probabilities for finding a system in an equilibrium power state $[4,5]$. The distribution received the name "Gibbs distribution" and, according to Feynman, it is "the top of statistical mechanics" [5]. However, Gibbs's approach is extraordinarily difficult. E.T. Jaynes [6] advanced another approach based on maximizing entropy according to Shannon. The relationship between Shannon's entropy and Boltzmann's entropy, which is widely used at the solution of problems of thermodynamics, is presented in $[5,7]$.

Jaynes idea is as follows. Let us consider a system in which the conditions cannot be calculated or measured by an experiment. However, each state of the system has a certain measured implication, the average value of which is known (or can be defined), and the average result of these implications is known from the statistical data. Then the most objective are probabilities of states maximizing Shannon's entropy under restrictions imposed by information about average implications of states.

Let us explain Jaynes' principle on the examples mentioned above. First, let us consider the situation with standard construction projects. Using the network schedule, it is possible to calculate how much delays in each phase will increase the time of the whole project's implementation. The appropriate calculations are usually carried out. Meanwhile, quite often PERT analysis is applied, and sometimes the methods of simulation modeling are used $[8,9]$. Let us allow that the project has $n$ phases and the standard delay of an $i$-th phase leads to the project delay for the period of $T_{i}$. It is established that the average delay of projects in the company is $T$. Let's denote the probability of a delay of $i$-th phase through $p_{i}$. Then it is possible to write an equation showing that the sum of $n$ multiplications $p_{i}$ by $T_{i}$ is equal to $T$. This represents the restriction under which it is necessary to find the distribution of probabilities at which the entropy reaches its maximum.

In a similar way, it is possible to find the distribution of probabilities of failure of railway automatic through the fault of particular service departments. Moreover, the task is reduced to the problem of maximizing Shannon's entropy. The consequences of the failures are the delays of trains measured in hours (such data are always recorded on the railroads). Knowledge of the probabilities of the undesirable states happening in the past allows us to focus resources on reducing the probabilities of states in the future which have the most serious consequences.

\section{Substantial definition of the problem of quality assessment of technical device restoration}

Let us give substantial statement of quality assessment for works of restoring technical devices in the case when restoration is carried out by replacement of elements. The organization has a fleet consisting of a significant number of similar technical devices. Each device consists of a certain number of elements among which there is an element which is worn out during its use. Its wear is indicated by deterioration of a certain parameter of system, the value of which may be measured. On achieving a certain value of this parameter, the worn-out element must be replaced with an operable spare element. Such a maintenance strategy allows us to avoid failure of the device [10]. For performing the replacement works, an organization (hereinafter - the Customer), negotiates a contract with a specialized organization (hereinafter the Contractor). There are three types of spare elements that may be used for replacement: new originals, new non-originals and restored elements. The contract specifies what percentage of spare elements of each type one is allowed to use. It is difficult for the Customer to check all the spare elements used for replacement. However, the Customer records the times between requirements 
for replacement of worn-out elements for each device served by the Contractor. Respectively, the Customer knows the average time between requirements for replacement.

The Customer wishes to know how fairly the Contractor is executing the contract, particularly, whether the Contractor exceeds the limits established for use of nonoriginal and restored elements.

\section{Mathematical definition of the problem of quality assessment of the restoration of technical devices}

The mathematical definition of the problem is as follows. A certain element of a technical device is repeatedly replaced with an operable spare element. Three types of spare elements are used: new originals, new non-originals and restored elements.

When using original spare elements, the average time before the following replacement is $t_{1}$, for non-original spare element the time is $t_{2}$, and for restored spare elements $-t_{3}$. The actual average time between replacements is $T$.

We are required to define the shares of original, nonoriginal and restored spare elements in the total number of replacements. After this, the shares are to be compared with the figures, specified in the contract.

\section{The solution of the task based on Jaynes' principle}

It is required that we determine the probabilities of transition of some faulty element to one of three states: "replaced with an original spare element" (a spare element of the first class), "replaced with a non-original spare element" (a spare element of the second class), "replaced with a restored spare element" (a spare element of the third class). Let us denote these probabilities through $p_{1}, p_{2}$ and $p_{3}$.

Then the average time between replacements (which is known) can be expressed through average times between replacements using spare elements of the first, second and third classes:

$$
T=p_{1} \cdot t_{1}+p_{2} \cdot t_{2}+p_{3} \cdot t_{3} \text {. }
$$

At the same time

$$
p_{1}+p_{2}+p_{3}=1
$$

According to Jaynes' principle, the most objective are those probabilities of states of the element for which, taking into account (1) and (2), Shannon's entropy reaches its maximum:

$H\left(p_{1}, p_{2}, p_{3}\right)=-p_{1} \cdot \ln p_{1}-p_{2} \cdot \ln p_{2}-p_{3} \cdot \ln p_{3} \rightarrow \max$

We will apply the method of Lagrange multipliers to find the maximum of the nonlinear function (3) under restrictions (1) and (2). After appropriate transformations, allowing exclusion of uncertain Lagrange multipliers, we discover that determining the probabilities is reduced to the solution of the system that consists of (1), (2) and the following equation:

$$
p_{1}^{t_{2}-t_{3}} \cdot p_{2}^{t_{3}-t_{1}} \cdot p_{3}^{t_{1}-t_{2}}=1 .
$$

The system of the equations (1), (2) and (4) can be solved by methods included in the Mathcad Prime package. When the required probabilities are found, it becomes possible to compare them with allowable values specified in the contract, and to make a judgement whether the divergence is essential.

\section{Example of calculation}

The results of the study were applied in practice. Let us give an example of calculations with real figures, but without disclosing the names of the organizations that are the Contractor and the Customer.

The Customer possesses a fleet of forty special cars used for construction of the railroads. In each car there is an important element which is subject to mechanical wear in use. The failure model is different from the exponential distribution of a time between failures with fixed intensity. There is an opportunity to reduce the probability of sudden failure of an element, replacing it by an obviously operable spare part. There are two possible strategies of replacement: based on a state and based on working hours of elements. Between them the first option is chosen, because the state of an element may be determined by the deterioration in easily measured car parameter. For replacement works, a contract between the Customer and a specialized repairing organization the Contractor - is negotiated and signed. In the contract, it is specified that the share of non-original spare elements used for replacements should not exceed $15 \%$ of all the replacements. For restored spare parts, such a limit is established at the level of $5 \%$ of all the replacements. The decision allowing use of non-original and restored spare elements is explained by the expensiveness of the original elements. For the Contractor, it is unprofitable to keep too large a volume of original elements, and the Customer does not wish to wait for delivery of such elements under an order. However, the concession is limited: 
the percentage of use of original spare elements should be not less than $80 \%$. If an original spare element is used, the average time before the subsequent replacement is 12 months. For non-original elements, such period is 8 months, and for restored elements -4 months.

In two years of operating the cars, after conclusion of a service contract, it was discovered that the average time between replacements of worn-out elements is 10.25 months. The customer was going to estimate how fairly the Contractor applies the limits of use of non-original and restored spare elements.

The calculations stated above were carried out using Mathcad Prime 3.1 software (the appropriate license was purchased by the Customer).

The following values for probabilities of use of spare elements of the first, second and third types were obtained: $p_{1}=0.66 ; p_{2}=0.25 ; p_{3}=0.09$.

Relying on the calculations, the Customer concluded that the limits were not followed, so a claim was made on the Contractor. The Contractor agreed with it and promised to avoid such deviations in the future.

Let us note the following point. At exact values of the limits, the average time $T_{\mathrm{o}}$ according to (1) should be 11 months. The fact that the actual value was equal to 10.25 months did not allow the Customer to make a convincing complaint. There was a doubt as to whether the deviation was within admissible limits. Calculation of the most likely values of probabilities of use of spare elements of various types allowed us to get an answer to this question.

There is another interesting fact. At the calculated values of probabilities $p_{1}, p_{2}$ and $p_{3}$ the entropy (3) is equal 0.844 nat. For the time of the values stated above, it is the greatest possible value of the entropy under the re- striction (1). The question arises: at what value $T$ does the entropy reach its maximum possible value for a case of three possible states of a replaced element? It is known that for fixed number of possible states of an object, the entropy of a random variable called "number of state" reaches an absolute maximum when probabilities of object states are equal. In our case, the greatest possible value of the entropy $H_{3}=\ln 3=1.1$ nat. It will be reached at $T_{3}$ equal to the average value of times between replacements of spare elements of different types. For the data under consideration $T_{3}$ is 8 months, and then $p_{1}=p_{2}=p_{3}=0.33(3)$.

\section{Conclusion}

For many real organizational and technical systems, there is an actual problem of determining probabilities of their availability in different possible states, while it is impossible to determine the probabilities by classical statistical methods because of the insufficient volume of source data or their low reliability. The Jaynes' information principle of determining the most objective probabilities of states of a complex system relying on their implications often helps to solve such problem. Using Jaynes' principle, the volume of required statistical data decreases dramatically.

In the presented paper, with the help of Jaynes' information principle, the problem of assessing the fairness of a contractor making replacement of wearing-out elements of technical devices is solved. The system of equations for determining the probabilities of using original, non-original and restored spare elements is presented. The practical application of the approach showed the high reliability of the results obtained and their practical usefulness.

\section{References}

1. Tsipes G.L., Tovb A.S. (2009) Proekty i upravlenie proektami v sovremennykh kompaniyakh [Projects and project management in modern companies]. Moscow: Olymp-Business (in Russian).

2. Boss V. (2015) Lektsii po matematike. Veroyatnost. Informatsiya. Statistika [Lectures on mathematics. Probability. Information. Statistics]. Moscow: LENAND (in Russian).

3. Lisenkov V.M. (1999) Statisticheskaya teoriya bezopasnosti dvizheniya poezdov [Statistical theory of trains traffic safety]. Moscow: VINITI RAN (in Russian).

4. Lavenda B. (1999) Statisticheskaya fizika. Veroyatnostnyiy podhod [Statistical physics. Probabilistic approach]. Moscow: Mir (in Russian).

5. Maron V.I. (2011) Statisticheskie modeli na osnove informatsionnogo podhoda Dzheynsa [Statistical models based on Jaynes' information principle]. Moscow: Max Press (in Russian).

6. Jaynes E.T. (2003) Probability theory: The logic of science. Cambridge: Cambridge University Press.

7. Chernavskiy D.S. (2001) Sinergetika i informatsiya. Dinamicheskaya teoriya informatsii [Synergetrics and information. Dynamic theory of information]. Moscow: Nauka (in Russian).

8. Akopov A.S. (2014) Imitatsionnoe modelirovanie [Simulation modeling]. Moscow: Urait (in Russian).

9. Isaev D.V. (2014) Modelirovanie realizatsii proektov vnedreniya analiticheskikh informatsionnykh sistem [Modeling of analytical information systems implementation projects]. Audit and Financial Analysis, no. 6, pp. 416-422 (in Russian).

10. Breydo A.I., Ovsyanikov V.A. (1983) Organizatsiya obsluzhivaniya zheleznodorozhnyih ustroystv avtomatiki i svyazi [Organization of service of railway devices of automatic equipment and communication]. Moscow: Transport (in Russian). 


\title{
Оценка качества обслуживания сложных технических устройств на основе информационного принципа Джейнса
}

\author{
А.И. Марон \\ кандидат технических наук, доцент кафедры бизнес-аналитики \\ Национальный исследовательский университет «Высшая школа экономики» \\ Адрес: 101000, г. Москва, ул. Мясницкая, д. 20 \\ E-mail:amaron@hse.ru
}

\begin{abstract}
Аннотация
Информационный принцип (формализм) Джейнса, предложенный для решения задач статистической термодинамики, применен для решения задачи об оценке добросовестности исполнителя, осуществляющего восстановление технической системы методом замены элементов.

Постановка задачи выглядит следующим образом. Заказчик обладает значительным парком однотипных технических устройств (например, автомобилей), определенные элементы которых подлежат плановой замене. По договору замену в плановом порядке осуществляет исполнитель. Для замены могут использоваться запасные элементы трех типов: новые оригинальные, новые неоригинальные и восстановленные. В договоре указано, какой процент запасных элементов каждого типа можно использовать. Заказчику затруднительно каждый раз проверять, какой именно элемент установлен. Однако для элемента каждого типа можно рассчитать среднее время до наступления момента, когда потребуется очередная замена. Фактическое среднее время между требованиями о замене фиксируется заказчиком.

На основе этих данных с помощью информационного принципа Джейнса можно найти наиболее объективные вероятности использования исполнителем элементов различных типов. Сравнив эти вероятности с лимитами, указанными в договоре, заказчик делает вывод о добросовестности исполнителя и, в случае необходимости, принимает необходимые меры. В соответствии с принципом Джейнса, наиболее объективными являются вероятности, при которых энтропия по Шеннону достигает максимума при заданных ограничениях. Соответственно, задача их нахождения сводится к задаче нахождения экстремума нелинейной функции при заданных ограничениях. В работе эта задача сформулирована математически и решена для случая трех переменных с помощью метода множителей Лагранжа. Приведен расчет для реальной ситуации из практики автора.
\end{abstract}

Ключевые слова: техническое обслуживание, вероятность, энтропия, принцип Джейнса.

Цитирование: Maron A.I. Assessment of service quality for complex technical devices based on the Jaynes' information principle // Business Informatics. 2016. No. 4 (38). P. 47-51. DOI: 10.17323/1998-0663.2016.4.47.51.

\section{Литература}

1. Ципес Г.Л., Товб А.С. Проекты и управление проектами в современных компаниях. М.: Олимп-Бизнес, 2009. 480 с.

2. Босс В. Лекции по математике. Вероятность. Информация. Статистика. М.: ЛЕНАНД, 2015. 224 с.

3. Лисенков В.М. Статистическая теория безопасности движения поездов. М: ВИНИТИ РАН, 1999. 332 с.

4. Лавенда Б. Статистическая физика. Вероятностный подход / Пер. с англ. М.: Мир, 1999. 432 с.

5. Марон В.И. Статистические модели на основе информационного подхода Джейнса. М.: Макс Пресс, 2011. 156 с.

6. Jaynes E.T. Probability theory: The logic of science. Cambridge: Cambridge University Press, 2003. 727 p.

7. Чернавский Д.С. Синергетика и информация. Динамическая теория информации. М.: Либроком, 2016. 302 с.

8. Акопов А.С. Имитационное моделирование. М.: Юрайт, 2014. 389 с

9. Исаев Д.В. Моделирование реализации проектов внедрения аналитических информационных систем // Аудит и финансовый анализ. 2014. № 6. С. 416-422.

10. Брейдо А.И., Овсяников В.А. Организация обслуживания железнодорожных устройств автоматики и связи. М.: Транспорт, 1983. $208 \mathrm{c}$. 